\title{
Qunurealy Distrim \\ Chronic hepatitis B in Nepal: An Asian country with low prevalence of HBV Infection
}

\author{
Santosh Man Shrestha and Shobhana Shrestha
}

\section{ABSTRACT}

Liver Foundation Nepal

Sitapaela Height

Kathmandu, Nepal

Correspondence:

Dr. Santosh Man Shrestha

Email: smshrestha1938@gmail.com

\begin{abstract}
Sandwiched between China, a country with high prevalence of hepatitis B surface antigen (HBsAg) and 30\% of the world's HBsAg carriers, and India which has intermediate HBsAg prevalence and $10 \%$ of the world's carriers, Nepal has the lowest prevalence of hepatitis $\mathrm{B}$ virus (HBV) infection in Asia, with an HBsAg carrier rate of $0.9 \%$. This treatise discusses the probable causes of this low prevalence based on published literature on the subject. The HBsAg prevalence among pregnant women in Nepal is low $(0.5 \%)$ and none of those examined were HBeAg positive. The highest prevalence of HBsAg was found in the 6-15 years age group. The low prevalence of this infection in the country was due to an absence of significant vertical transmission and its predominant spread by horizontal transmission among the adolescent age group.
\end{abstract}

KEYWORDS: Hepatitis in Nepal, epidemiology of hepatitis B, hepatitis B virus infection.

\section{Introduction}

Hepatitis B is a common viral infection of man. In about $5 \%$ of the infected persons the infection becomes chronic as indicated by persistence of hepatitis B surface antigen ( $\mathrm{HBsAg}$ ) in blood for more than six months. Persons with chronic hepatitis B are at risk of developing liver cirrhosis (LC) and hepatocellular carcinoma (HCC). There are about 400 million chronic carriers of the virus in the world. ${ }^{1}$ Global prevalence of chronic hepatitis $B$ virus (HBV) infection varies greatly and countries are defined under low, intermediate or high prevalence regions based on the HBsAg prevalence of $<2 \%, 2-7 \%$ and $\geq 8 \%$, respectively. ${ }^{2}$

Hepatitis B is a parenterally transmitted virus that has adapted for its existence to the basic human activities like close association, sex and child-birth. Transmission of the virus occurs in community in three waves. First wave occurs during perinatal period when the virus is transmitted from infected mothers to infants during delivery and up to first year of life. Second wave of transmission occurs during childhood by C Tropical Gastroenterology 2012 horizontal spread through close contact with infected siblings, father, relatives and friends. And the third wave of spread occurs during adult life through sexual contact, intravenous drug abuse, blood transfusion etc. The risk of chronicity is determined by the age at which the infection is acquired. ${ }^{3}$ The infection becomes chronic in $90 \%$ among who acquire the infection vertically during the perinatal period up to 1 year of age. The risk of chronic infection is about $30 \%$ when it's acquired between 1-5 years of age. And it is only about $2 \%$ when the infection is acquired after 5 years of age or in adulthood. Major mode of spread in countries with high disease prevalence like China and Pacific countries is through vertical transmission. In Afro-Asian countries with intermediate prevalence predominant horizontal transmission has been noted during early childhood; and in low prevalence areas of North America, Western Europe and Australia it is through sexual or percutanous transmission during adulthood. 
Asian countries are generally classified as moderate to high prevalence regions of $\mathrm{HBV}$ infection. ${ }^{4} \mathrm{Nepal}$ is a small country wedged between China in the north, with a high prevalence of HBV infection with nearly 120 million $\mathrm{HBsAg}_{\text {carrier population }}{ }^{5}$ and India in the south with an intermediate prevalence of the infection and nearly 40 million HBsAg carriers. ${ }^{6}$ Nepal is unique in having a low prevalence of HBV infection. ${ }^{7}$ This treatise discusses the possible causes for the low prevalence of the HBV infection in Nepal based on published literature on the subject.

\section{Community prevalence of HBsAg in Nepal}

Nepal is geographically divided into 3 regions, the Himalayan region in the north bordering China, the hilly region in the middle and the planes or the Terai region in the south bordering India. It is a multi-ethnic country and its 30 million people belong to more than 25 distinct ethnic groups. ${ }^{8}$ The first report on the prevalence of HBV infection in Nepal was a community study published in $1990 .^{7}$ The study included 2,555 normal subjects (1026 males and 1529 females) of different age groups, belonging to different ethnic backgrounds, from five areas spread over different geographic regions of the country. The study (Table 1) showed that the prevalence of HBsAg in Nepal was $0.9 \%$ ( $1.6 \%$ among males and $0.5 \%$ among females). HBsAg was not detected in children below 5 years of age. Highest prevalence of HBsAg of $2.2 \%$ was detected in the 6-15 years age group and it rapidly declined as the age advanced. The shape of the anti-HBs curve was different. It progressively increased from $4.2 \%$ in 6-15 years age group to $10 \%$ in above 41 years age group. The low prevalence of HBsAg among Nepalese was confirmed by another study in 14,300 blood donors $^{9}$ and young adults that included 2,585 healthy adult males from different geographic regions of Nepal. ${ }^{10-12}$

\section{HBsAg prevalence in pregnant women}

The prevalence of HBsAg, anti-HBs and anti-HBc in 722 pregnant women from different ethnic backgrounds in the Kathmandu valley was noted to be $0.5 \%, 7.3 \%$ and $28.5 \%$, respectively. ${ }^{13}$ The overall infection rate (presence of any of the above markers of HBV infection) was $36 \%$. None of the HBsAg positive pregnant women were $\mathrm{HBeAg}$ positive and $50 \%$ were anti-HBe positive. None of the persons with HBV markers gave history of jaundice. These observations suggested that HBV occurred in the community as a transient asymptomatic infection with low level of chronicity.

\section{Prevalence of $\mathrm{HBV}$ infection among household contacts of persons with chronic HBV infection}

The extent and mode of spread of HBV infection from persons with chronic HBV infection was assessed in a study on 186 close relatives of $45 \mathrm{HBsAg}$ carriers (10 asymptomatic carriers and 35 with chronic liver disease and HCC). ${ }^{14}$ Clusters of HBV infection were found among household contacts of persons with chronic $\mathrm{HBV}$ infections. The incidence of $\mathrm{HBsAg}$ antigenemia was highest among the siblings (31\%) compared to offspring $(20.5 \%)$ or spouses $(17.7 \%)$ of the index cases (Table 2), which suggested that predominant horizontal transmission of the infection occurred in this community. A very low incidence of acute hepatitis B of 3-9\% among adult patients with acute viral hepatitis ${ }^{15,16}$ suggested that sexual transmission is unlikely to be a common mode of spread of the infection in Nepal.

\section{An area with intermediate prevalence of HBsAg in Nepal}

The Surkhet valley is situated in west Nepal and has a population of 26,000 (1981 census). Forty-five percent of the people in the valley are below 15 years of age. The valley was initially inhabited mainly by Tharus, an indigenous forest tribe. The Tharus women adopt universal practices of extensive decorative tattooing in arms, legs and chest; and ear and nose piercing for ornamental purpose in girls starting from 5 years

Table1: Prevalence of Hepatitis B markers in different age groups in Nepal*

\begin{tabular}{lccccc}
\hline Age Group & Number & HBsAg+ & \% & Anti-HBs+ & \% \\
\hline $0-5$ yrs & 57 & 0 & 0.0 & 5 & 8.8 \\
$6-15$ yrs & 359 & 8 & 2.2 & 15 & 4.2 \\
$16-41$ yrs & 1788 & 16 & 0.9 & 158 & 8.8 \\
41 yrs + & 351 & 2 & 0.6 & 35 & 10.0 \\
Total & 2555 & 26 & 0.9 & 214 & 8.4 \\
\hline Male & 1026 & 17 & 1.6 & 76 & 7.4 \\
Female & 1529 & 9 & 0.5 & 138 & 9.0 \\
\hline
\end{tabular}

* adopted from reference no 7.

Table 2: Prevalence of HBsAg, anti-HBs and anti-HBc among close family contact of chronic carriers of HBsAg in Nepal*

\begin{tabular}{lccccc}
\hline $\begin{array}{l}\text { Relation to } \\
\text { Index case }\end{array}$ & $\mathbf{N}$ tested & $\begin{array}{c}\text { \% +ve } \\
\text { HBsAg }\end{array}$ & $\begin{array}{c}\text { Anti- } \\
\text { HBs }\end{array}$ & $\begin{array}{c}\text { Anti- } \\
\text { HBc }\end{array}$ & $\begin{array}{c}\text { Total HBV } \\
\text { Infection (\%) }\end{array}$ \\
\hline Spouse & 34 & 17.7 & 44.1 & 24.1 & 61.8 \\
Offspring & 73 & 20.5 & 23.3 & 29.6 & 43.8 \\
Sibling & 29 & 31.0 & 38.0 & 64.3 & 69.0 \\
\hline
\end{tabular}

*adopted from reference no 14 
of age. At the time of the study Tharus constituted only about $12 \%$ of the population of the valley. Among other inhabitants of the valley that included Brahmin (17\%), Chetris (16\%), Magars (15\%) Kami (9\%) and Sunar (6\%), ear and nose piercing in females above 5 years age is equally common. Given these community customs the valley was chosen for elucidating the prevalence of HBV infection. The prevalence of HBsAg and anti-HBs in the valley was $6.6 \%$ (4.4\% in males and $9.8 \%$ in females) and $35 \%$ respectively, ${ }^{17}$ which was much higher than the national average. $\mathrm{HBeAg}$ was positive in $14 \%$ and anti$\mathrm{HBe}$ was positive in $21 \%$ and neither was detected in $64 \%$ (Table 3). The study showed that the valley had intermediate prevalence of infection with higher prevalence of HBsAg among females, probably due to the common practice of tattooing and body piercing among them.

\section{Ethnic groups with intermediate and high prevalence of $\mathrm{HBV}$ infection in Nepal}

Some ethnic groups in Nepal like the Gurung from the Manang region near the Tibetan border (unpublished data) and Sherpa from Solu-Khumbu area at the base of Mt. Everest have intermediate prevalence of HBsAg. Gurung and Sherpa constitute $1.23 \%$ and $0.66 \%$ of the population of Nepal. Among the 245 (90 males and 155 females) healthy individuals from Manang examined in the year 2000, HBsAg was positive in $7.3 \%$, and anti-HBs in 35\%. Similarly a study done on 600 Sherpas by a New Zealand group based at the Kundi hospital near the Everest base camp detected HBsAg prevalence of $3.5 \% .^{18}$

High prevalence of HBsAg was detected in the Tibetans living in Nepal. ${ }^{19}$ Tibetans arrived in Nepal as political refugees in 1959. There were about 18,000 Tibetans settled in 13 districts in Nepal in 2002. A study to examine this group included 375 Tibetans of different ages living in three settlement areas including, Hemza, Tashi Ling in Pokhara and Jawalkhel in Kathmandu valley. The presence of HBV markers, anti-HCV and anti-HEV IgG among them were compared with 540 Nepalese living around these areas. The prevalence of HBsAg among Tibetans was $16 \%$ compared to $0.7 \%$ among the Nepalese (Table 4). The dominant HBsAg subtype in Tibetans was 'ayw'. HBeAg was positive in $26 \%$ of the Tibetan women positive for HBsAg (Table 5). The prevalence of HBsAg and HBeAg among children in 0-9 year age group among Tibetans was $20 \%$ and $71 \%$, respectively, compared to the absence of HBsAg among Nepalese in the same age group. It was estimated that $27 \%$ of HBsAg in children in this community was contributed by perinatal transmission (Table 6). Vertical transmission was thus considered an important mode of HBV

Table 3: Prevalence of HBV markers among inhabitants of Surkhet valley, Nepal*

\begin{tabular}{lcccc}
\hline $\begin{array}{l}\text { Age group } \\
\text { in years }\end{array}$ & Case & $\begin{array}{c}\text { HBsAg } \\
\text { (RPHA) }\end{array}$ & Case & $\begin{array}{c}\text { Anti-HBs } \\
\text { (RIA) }\end{array}$ \\
\hline $0-10$ & 45 & $6.6 \%$ & 18 & $22.2 \%$ \\
$11-20$ & 65 & $3.0 \%$ & 30 & $46.6 \%$ \\
$21-40$ & 82 & $9.7 \%$ & 43 & $44.0 \%$ \\
$41+$ & 33 & $6.0 \%$ & 12 & $25.0 \%$ \\
\hline Total & 225 & $6.6 \%$ & 103 & $35.0 \%$ \\
\hline HBsAg: Male 4.4\%, Female 9.8\% & \\
HBeAg (+ ): $14 \%$ \& anti-HBe (+) 21\% \\
$*$ adopted from ref no 15
\end{tabular}

Table 4: Comparison of Hepatitis B viral markers between Tibetans in Nepal \& Nepalese *

\begin{tabular}{lcccccc}
\hline & \multicolumn{3}{c}{ TIBETANS } & \multicolumn{3}{c}{ NEPALESE } \\
Age (yr) & Cases & HBsAg & Anti-HBV & Cases & HBsAg & Anti-HBV \\
\hline $0-9$ & 34 & $20.0 \%$ & $32.0 \%$ & 113 & 0 & $3.5 \%$ \\
$10-19$ & 79 & $10.0 \%$ & $39.0 \%$ & 198 & $0.5 \%$ & $5.0 \%$ \\
$20-29$ & 106 & $18.0 \%$ & $55.0 \%$ & 110 & $1.8 \%$ & $5.4 \%$ \\
$30-39$ & 61 & $20.0 \%$ & $46.0 \%$ & 49 & 0 & $32.6 \%$ \\
$40-49$ & 95 & $15.0 \%$ & $36.0 \%$ & 25 & 0 & $16.0 \%$ \\
$50+$ & $\mathrm{NT}$ & & & 45 & $2.2 \%$ & $7.8 \%$ \\
\hline Total & 375 & $16 \%$ & $45.0 \%$ & 540 & $0.7 \%$ & $36.0 \%$ \\
\hline
\end{tabular}

anti-HBV = anti-HBs and/or anti-HBc without $\mathrm{HBsAg}$

* adopted from ref no 17

Table 5: Frequency of $\mathrm{HBeAg}$ among HBsAg positive Tibetan Women*

\begin{tabular}{lccc}
\hline Age & Case & HBsAg & HBeAg \\
\hline $20-29$ & 71 & $18 \%$ & $31 \%$ \\
$30-39$ & 8 & $17 \%$ & $25 \%$ \\
$40-49$ & 6 & $15 \%$ & $17 \%$ \\
\hline Total & 157 & $17 \%$ & $26 \%$ \\
\hline
\end{tabular}

* adopted from ref no 17

Table 6: Estimation of the impact of perinatal transmission in the prevalence $\mathrm{HBV}$ infection among Tibetan children in Nepal*

\begin{tabular}{|c|c|}
\hline $\begin{array}{l}\text { - Prevalence of HBsAg among perinatal } \\
\text { women aged } 20-49 \text { yrs }\end{array}$ & $17 \%$ \\
\hline $\begin{array}{l}\text { - Prevalence of HBeAg among the above } \\
\text { group }\end{array}$ & $26 \%$ \\
\hline $\begin{array}{l}\text { Prevalence of HBsAg carrier mothers } \\
\text { with } \mathrm{HBeAg}\end{array}$ & $4.4 \%(=17 \% \times 0.26)$ \\
\hline $\begin{array}{l}\text { - Frequency of HBV carriers in community } \\
\text { due to perinatal transmission }\end{array}$ & $35 \%(=4.4 \% \times 0.8 *)$ \\
\hline $\begin{array}{l}\text { Prevalence of HBsAg among children } \\
\text { aged } 0-19 \text { yrs }\end{array}$ & $13 \%(15 / 113)$ \\
\hline $\begin{array}{l}\text { - Ratio of perinatal transmission causing } \\
\text { HBV infection in children }\end{array}$ & $27 \%(35 \%$ of $13 \%)$ \\
\hline
\end{tabular}


spread among Tibetans in Nepal. This study done 10 years after the first community study (Table 1) also demonstrated the persistent low prevalence of HBsAg among the Nepalese.

Other high risk groups for HBV infection in Nepal as in other countries included, commercial sex workers with HBsAg $10.9 \%,{ }^{20}$ drug addicts with $3-6 \%,{ }^{21,22}$ patients with chronic renal failure on hemodialysis $2 \%,{ }^{21}$ soldiers $(3 \%)^{22}$ and health-care workers $2 \% .{ }^{23}$

\section{HBsAg sub-types and HBV DNA genotypes in Nepal}

The common HBsAg subtypes in Nepal are 'ayw' (47\%) and 'adw' (34.3\%). Only 4\% of the HBsAg were 'adr' and unusual subtypes like 'ad', 'ay', and 'a' occur rarely in Nepal. ${ }^{24}$ The predominant HBV genotypes in Nepal include D (69\%) and A $(22 \%) .{ }^{25}$ Mixed infections (4.4\%) and infections with genotype C (4.4\%) occur rarely. Another important feature of HBV epidemiology in Nepal is the absence of associated hepatitis D virus infection ${ }^{17,23,26}$ and the near absence of hepatitis $\mathrm{C}$ virus (HCV) co-infection, except among drug addicts (5.7\%) who are anti-HCV positive. ${ }^{23}$

\section{Discussion}

The low prevalence of HBsAg of $<0.9 \%$ in Nepal is now well established. Nepal is the only country in Asia other than Japan known to have low prevalence of HBV infection. ${ }^{27,28}$ This low prevalence observed in Nepal is similar to that seen in North America, Western Europe and Australia where transmission of the infection occurs mainly during adulthood. ${ }^{2}$ Vertical transmission is the main mode of spread in China with its high prevalence of infection (HBsAg 10\%). ${ }^{5}$ South Asian countries around Nepal have an intermediate prevalence of infection ${ }^{6,29-}$ ${ }^{38}$ where it is known to spread horizontally during early childhood. Why despite Nepal's location between countries with high and intermediate prevalence, the country has low prevalence of $\mathrm{HBV}$ infection? What constitutes the main mode of spread of HBV infection in Nepal? These are the questions that come to the fore in light of the data presented above.

\section{Possible cause for low prevalence of $\mathrm{HBV}$ infection in Nepal}

In South Asian countries the prevalence of HBsAg among pregnant women varies from $2.5 \%$ to $3.8 \%{ }^{30,35,37}$ and about $7.8 \%$ to $30.2 \%$ of them are $\mathrm{HBeAg}$ positive (Table 7). Vertical transmission of the infection thus occurs only in a small proportion of pregnant women positive for $\mathrm{HBeAg}$, creating a small pool of highly infective young children. This assumption is supported by the finding of HBsAg prevalence of 3.2-6\% in children below 5 years of age (Table 7). ${ }^{30,31,33,36}$ Ninety per cent of these are likely to be chronic carriers. These highly infective children further amplify the infection in the community by horizontal transmission to other children during the early childhood period. About $30 \%$ of those infected within 5 years of age become chronic carriers of the virus, a process that contributes to making these countries a region of intermediate prevalence of $\mathrm{HBV}$ infection.

The low prevalence of $\mathrm{HBsAg}$ among pregnant women in Nepal, none of whom are $\mathrm{HBeAg}$ positive, suggests that perinatal transmission of the infection is rare in this country. ${ }^{13}$ A study among household contacts of persistent $\mathrm{HBsAg}$ carriers in Nepal suggested that horizontal spread among siblings is more common than sexual or vertical transmission. ${ }^{14}$ The absence of HBsAg in children below 5 years of age (Tables $1 \& 3$ ) and the high prevalence HBsAg in young adults around the age of 15 years suggests that horizontal transmission of HBV in Nepal occurs predominantly in the adolescent age group. The incidence of chronic HBV infection among those who acquire infection after the age of 5 years is about $2 \%$, similar to that when the infection is acquired in adulthood, as in the West. Thus it's noteworthy that other countries of South Asia where horizontal transmission occurs in early childhood have intermediate prevalence, whereas in Nepal where horizontal transmission occurs at adolescence has low prevalence of HBV

Table 7: Prevalence of HBsAg in pregnant women and children in different Asian countries

\begin{tabular}{|c|c|c|c|c|c|c|c|}
\hline \multirow[t]{2}{*}{ Country } & \multicolumn{2}{|c|}{ Population } & \multicolumn{2}{|c|}{ Pregnant women } & \multicolumn{2}{|c|}{ Children $<5$ yrs } & \multirow[t]{2}{*}{ Ref } \\
\hline & HBsAg & HBeAg & HBsAg & HBeAg & HBsAg & HBeAg & \\
\hline Bangladesh & $4.8 \%$ & - & $3.8 \%$ & $30.2 \%$ & $3.2 \%$ & - & 31 \\
\hline India & $4.7 \%$ & 7.0 & $2.8 \%$ & $7.8 \%$ & $1.9 \%$ & - & $6,25-30$ \\
\hline Pakistan & $4.0 \%$ & - & $2.5 \%$ & $17.0 \%$ & $1.8 \%$ & - & $32-33$ \\
\hline Nepal & $0.9 \%$ & - & $0.5 \%$ & $0 \%$ & 0 & - & 7,13 \\
\hline Tibetans in Nepal & $16.0 \%$ & $28.0 \%$ & $17.0 \%$ & $26.0 \%$ & $20.0 \%$ & $71 \%$ & 17 \\
\hline China & $9.8 \%$ & $31.9 \%$ & & & $9.8 \%$ & $53 \%$ & 5 \\
\hline
\end{tabular}


Table 8: Four patterns of chronic hepatitis B infection

1st pattern: China \& other Asia-Pacific countries

Vertical Transmission of HBV infection (CHB 90\%)
Prolonged Immune tolerant Phase

Children have $\mathrm{HBeAg}+$, High level of

HBV DNA \& normal ALT

2nd pattern: South Asia, Africa \& Mediterranean countries

Horizontal transmission in early childhood (CHB 30\%) Children: HBeAg +, ALT level high

3rd pattern: Western countries

Transmission of infection adulthood (CHB 2\%)

4th pattern: Nepal

Horizontal transmission in adolescent age (CHB 2\%)

\author{
CHB in adults, ALT \& HBVDNA \\ levels high
}

$\mathrm{HBeAg}$ sero-conversion in early adult age: $\mathrm{HBeAg}$-, anti-HBe+, low level of HBV DNA
High incidence of LC \& HCC in 6th to

7 th decades

$\mathrm{HBe} A g$ sero-conversion in adolescent age

Response to anti-viral therapy good

LC \& HCC related to Hepatic Vena Cava Disease infection.

Within Nepal however, there is one area (Surkhet valley in west Nepal) and two communities (Gurung and Sherpa living in high Himalayan area) which have been identified to have intermediate prevalence and a migrant Tibetan community with high prevalence of HBV infection. The mode of spread of infection in these intermediate prevalence communities/areas of Nepal is probably horizontal in early childhood as in seen in other South Asian countries and indicated by an HBsAg prevalence of $6.6 \%$ in the 0 to 10 years age group and $\mathrm{HBeAg}$ prevalence of $14.0 \%$ in Surkhet. The mode of spread among the Tibetans who have high prevalence of the infection is vertical as seen in China. ${ }^{19}$ The Tibetan community in Nepal has thus retained the $\mathrm{HBV}$ epidemiology of their original homeland.

The predominant HBV genotypes in high prevalence areas of Asia where vertical transmission occurs are genotype B and C. ${ }^{4}$ In low prevalence areas of the West, the infection is predominantly due to genotypes $\mathrm{A}$ and $\mathrm{D}$, acquired primarily in adulthood. The common HBV genotype in Nepal is D as in India ${ }^{30}$ and Pakistan. ${ }^{37} \mathrm{HBV}$ genotypes however, do not seem to play any role in determining the prevalence of infection in the community.

\section{Patterns of CHB infection}

The age distribution, mode of transmission and the prevalence of hepatitis B in community have important clinical significance as they help determine the pattern of infection and successful strategies for their clinical management. Three pattern of $\mathrm{CHB}$ are described (Table 8). ${ }^{40}$ The first pattern is seen in China and adjoining Asian and Pacific countries where perinatal transmission occurs with very high incidence (90\%) of CHB.
Here children with $\mathrm{CHB}$ have prolonged immune tolerant phase with $\mathrm{HBeAg}(+)$, high level of HBV-DNA and normal ALT level. $\mathrm{HBeAg}$ sero-conversion $[\mathrm{HBeAg}(-)$ and anti-HBe(+)] occurs a few decades later. Some patients have persistent $\mathrm{HBeAg}$ titers and develop persistent or intermittent ALT elevation. Persons with high HBV-DNA and normal ALT levels do not responds to anti-viral treatment but those with high ALT levels respond better to treatment and witness $\mathrm{HBeAg}$ seroconversion. A high proportion of these continue to maintain detectable levels of HBV-DNA even after definitive seroconversion. Carriers with this pattern of $\mathrm{CHB}$ infection tend to develop liver cirrhosis and HCC by sixth to seventh decades of infection. ${ }^{40,41}$ The second pattern of CHB infection is seen in South Asia, Africa and Mediterranean countries where horizontal transmission occurs with high incidence (30\%) of CHB. Children with $\mathrm{CHB}$ in this group are $\mathrm{HBeAg}(+)$ with high ALT levels and HBeAg sero-conversion tends to occur in late childhood or teenage. The third pattern is seen in the West where HBV infection occurs in adulthood through sexual exposure, IV drug abuse or transfusion of infected blood products, with low $(2 \%)$ level of CHB infection. Patients with CHB in this group have high ALT and HBV-DNA levels and they tend to respond to anti-viral treatment.

A fourth pattern of CHB infection is seen in Nepal (Table 8), where transmission of the infection occurs horizontally during adolescence with low prevalence of CHB infection. Majority of adults with CHB infection in Nepal are $\mathrm{HBeAg}(-)$, anti-HBe(+), have normal ALT levels and low levels of HBVDNA (unpublished data). And much of LC and HCC in Nepal are related to disease of the hepatic portion of inferior vena caval disease. ${ }^{25,27,42}$ Thus among Asian countries Nepal and Japan have low prevalence of HBV infection. While LC and $\mathrm{HCC}$ in Japan are predominantly related to chronic HCV 
infection, ${ }^{27,43}$ the same in Nepal is related to hepatic vena caval disease.

\section{Conclusion}

Nepal a country poised between two large nations China in the north with a $10 \% \mathrm{HBs}$ Ag carrier rate and India in the south with a $5 \%$ carrier rate, interestingly has a markedly low prevalence of $0.9 \%$. The low prevalence of $\mathrm{HBV}$ infection in Nepal is due to its spread among adolescents by horizontal transmission. An absence of early childhood transmission was is because of lack of vertical transmission and low prevalence of active infection among pregnant women. This unique HBV distribution and transmission pattern suggests a fourth pattern of CHB infection with $\mathrm{HBeAg}(-)$, anti-HBe(+), normal ALT levels and low HBV-DNA levels among the population of Nepal. It is also noteworthy that of the bulk of LC and HCC cases in Nepal are related to hepatic vena caval disease.

\section{References}

1. Lee WM. Hepatitis B virus infection. $N$ Engl J Med. 1997;337:1733-45.

2. Lok AS, McMohan BJ. Chronic hepatitis B: update 2009. Hepatology. 2009;50:661-2.

3. Lai CL, Ratziu V, Yuen MF, Poynard T. Viral hepatitis B. Lancet. 2003;362:2089-94.

4. Ahn SH, Chan HL, Chen PJ, Cheng J, Goenka MK, Hou J, et al. Chronic hepatitis B: whom to treat and for how long? Propositions, challenges, and future directions. Hepatol Int. 2010;4:386-95.

5. Xia GL, Liu CB, Cao HL, Bi SL, Zhan MY, Su CA, et al. Prevalence of hepatitis $\mathrm{B}$ and $\mathrm{C}$ virus infection in the general Chinese population: Results from a nationwide cross-sectional seroepidemiologic study of hepatitis A, B, C, D and E virus infections in China, 1992. Int.Hepatol Commun. 1996;5:62-73.

6. Thyagarajan SP, Jayaram S, Mohanavalli B. Prevalence of HBV in the general population in India. In: Sarin SK, Singal AK, editors. Hepatitis B in India. New Delhi: CBS publishers \& Distributors; 1996. p. 5-16.

7. Shrestha SM. Seroepidemiology of hepatitis B in Nepal. $J$ Commun Dis. 1990;22:27-32.

8. Bista DB. Peoples of Nepal, Ratna Pustak Bhandar, Kathmandu, Nepal; 2004.

9. Sharma BD, Booth K, Booth PB, Kenrick K. Results of testing for HBsAg on Nepalese blood donors by counterimmunoelectrophoresis. J Nep Med Ass. 1981;19:1

10. Rai SK, Shibata H, Pokharel BM, Bhandari RK. Prevalence of HBsAg and anti-HBsAg antibody in healthy college level Nepalese students. J Inst Med (Nepal). 1987:9:281-4.

11. Mertens T, Tondorf G, Siebolds M, Kruppenbacher JP, Shrestha SM, Mauff G, et al. Epidemiology of HIV and hepatitis B virus
(HBV) in selected African and Asian population. Infection. 1989;17:4-7.

12. Bidya S. HBsAg carriers among healthy Nepalese men: a serological survey. J Health Popul Nutr. 2002;20:235-8.

13. Shrestha SM. Incidence of HBsAg carrier rate in pregnant women in Kathmandu. J Inst Med. 1987;71-6.

14. Shrestha SM, Shrestha IN, Maharjan KG. Family clustering of HBV infection in the household of persistent HBsAg carriers: spread of HBV by horizontal transmission. J Inst Med. 1991;13:319-26

15. Shrestha SM. Acute sporadic viral hepatitis in Nepal. Trop Gastroenterol. 1987;8:99-105.

16. Shrestha SM, Shrestha S, Tsuda F, Nishizawa T, Gotanda Y, Takeda N, et al. Molecular investigation of hepatitis $\mathrm{E}$ virus infection in patients with acute hepatitis in Kathmandu, Nepal. $J$ Med Virol. 2003;69:207-14.

17. Shrestha SM. Seroepidemiology of viral hepatitis in Surkhet, Nepal. J Inst Med. 1987;9:1-10.

18. Chettri, J, Kundi Hospital, Solukhumbu, 2000 (personal communication).

19. Shrestha SM, Takeda N, Tsuda F, Okamoto H, Shrestha S, Shrestha VM. High prevalence of hepatitis B virus infection among Tibetans in Nepal. Trop Gastroenterol. 2002:23:63-5.

20. Bhatta P, Thapa S, Neupane S, Baker J, Friedman M. Commercial sex workers in Kathmandu valley: profile and prevalence of sexually transmitted disease. JNMA J Nepal Med Assoc. 1993;32:191-203.

21. Shrestha SM, Shrestha DM, Gafney TE, Maharjan KG, Tsuda F, Okamoto H. Hepatitis B and C infection among drug abusers in Nepal. Trop Gastroenterol. 1996;17:212-3.

22. Shrestha SM, Shrestha S, Tsuda F, Sawada N, Tanaka T, Okamoto $\mathrm{H}$, et al. Infection with $\mathrm{GB}$ virus $\mathrm{C}$ and hepatitis $\mathrm{C}$ virus in drug addicts, patients on maintenance hemodialysis, or with chronic liver disease in Nepal. J Med Virol. 1997;53:157-61.

23. Shrestha SM. Subedi NB, Shrestha S, Mahajan KG, Tsuda F, Okamoto H. Epidemiology of hepatitis C virus infection in Nepal. Trop Gastroenterol. 1998;19:102-4.

24. Shrestha SM. Tsuda F, Okamoto H, Tokita H, Horikita H, Tanaka T, Miyakawa Y, Mayumi M. Hepatitis B virus subtypes and hepatitis $\mathrm{C}$ virus genotypes in patients with chronic liver disease in Nepal. Hepatology. 1994;19:805-9.

25. Shrestha SM, Shrestha S, Shrestha A, Tsuda F, Endo K, Takahashi $\mathrm{M}$, et al. High prevalence of hepatitis B virus infection and inferior vena cava obstruction among patients with liver cirrhosis or hepatocellular carcinoma in Nepal. $J$ Gastroenterol Hepatol. 2007;22:1921-8.

26. Shrestha SM, Tsuda F. Hepatitis Delta virus infection in Nepal. Trop Gastroenterol. 1992;12:185-7.

27. Lemon SM, Layden TJ, Seeff L, Suzuki H, Nishioka K, Mishiro $\mathrm{S}$, et al. The $20^{\text {th }}$ United States-Japan joint hepatitis panel meeting. Hepatology. 2000;31:800-6.

28. Mohamed R, Desmond P, Suh DJ, Amarapurkar D, Gane E, Guangbi Y, et al. Practical difficulties in the management of hepatitis B in the Asia-Pacific region. J Gastroenterol Hepatol. 2004;19:958-9.

29. Tandon BN, Acharya SK, Tandon A. Epidemiology of hepatitis B virus infection in India. Gut. 1996;38:S56-9. 
30. Nayak NC, Panda SK, Zuckerman AJ, Bhan MK, Guha DK. Dynamics and impact of perinatal transmission of hepatitis B virus in North India. J Med Virol. 1987;21:137-45.

31. Tandon BN, Irshad M, Raju M, Mathur GP, Rao MN. Prevalence of HBsAg \& anti-HBs in children and strategy suggested for immunization in India. Ind J Med Res. 1991;93:337-9.

32. Chowdhury A, Santra A, Chakravorty R, Banerji A, Pal S, Dhali GK, et al. Community-based epidemiology of hepatitis B virus infection in West Bengal, India: prevalence of hepatitis B e-antigen negative infection and associated viral variants. J Gastroenterol Hepatol. 2005;20:1712-20.

33. Qamer S, Shahab T, Alam S, Malik A, Afzal K. Age-specific prevalence of hepatitis B surface antigen in pediatric population of Aligarh, North India. Indian J Pediatr. 2004;71:965-7.

34. Kant L, Hall AJ. Epidemiology of childhood hepatitis B in India: vaccination related issues. Indian J Pediatr. 1995;62:635-53.

35. Rumi MA, Begum K, Hassan MS, Hasan SM, Azam MG, Hasan $\mathrm{KN}$, et al. Detection of hepatitis B surface antigen in pregnant women attending a public hospital for delivery: implication for vaccination strategy in Bangladesh. Am J Trop Med Hyg. 1998;59:318-22.

36. Khan M, Ahmad N. Seroepidemiology of HBV and HCV in Bangladesh. Int.Hep Comm. 1996;5:27-9.

37. Jafri W, Jafri N, Yakoob J, Islam M, Tirmizi SF, Jafar T, et al.
Hepatitis B and C: prevalence and risk factors associated with seropositivity among children in Karachi, Pakistan. BMC Infectious diseases. 2006;6:101.

38. Zuberi SJ. Hepatitis B: Pakistan perspectve. National consensus conference on guidelines for hepatitis B and C, Karachi, 2003.

39. Ahmed CS, Wang ZH, Bin Z, Chen JJ, Kamal M, Hou JL. Hepatitis B virus genotypes, subgenotypes, precore, and basal core promoter mutations in two large provinces of Pakistan. $J$ Gastroenterol Hepatol. 2009;24:569-73.

40. Keeffe EB, Dietrich DT, Han SH, Jacobson IM, Martin P, Schiff $\mathrm{ER}$, et al. A treatment algorithm for the management of chronic hepatitis B virus infection in the United States. Clinical Gastroenterol \& Hepatol. 2004;2:87-106.

41. Lau GK, Carman WF, Locarnini SA, Okuda K, Lu ZM, Williams $\mathrm{R}$, et al. Treatment of chronic hepatitis B virus infection: an Asian-Pacific perspective. J Gastroenterol Hepatol. 1999;14:3-12.

42. Shrestha SM. Liver cirrhosis and hepatocellular carcinoma in hepatic vena cava disease, a liver disease caused by obstruction of inferior vena cava. Hepatol Int. 2009;3:392-402.

43. Yoshizawa H. Hepatocellular carcinoma associated with hepatitis $\mathrm{C}$ virus infection in Japan: projection to other countries in the foreseeable future. Oncology. 2002;62:8-17. 